\title{
(20) WILEY
}

\section{Human Psychopharmacology}

Measures and Methods, Volumes One and Two

Edited by I. HINDMARCH, Human Psychopharmacology

Research Unit, University of Leeds, UK and P.D. STONIER,

Medical Department, Hoechst UK Ltd, Middlesex, UK

Containing papers by distinguished international authors, these books cover a range of topics and reflect the diversity of the discipline of Human Psychopharmacology.

In Volume 1 subjects discussed include:- Assessment of Psychopathology; Construct Validity of Rating Scales for Melancholia; The Conceptual Basis of Anxiety; The Assessment of Stress; Psychomotor Tests in Psychopharmacology; The Assessment of Human Information-Processing Abilities in Psychopharmacology.

In Volume 2, the importance of measurement is illustrated when internationally respected researchers provide an insight into the way comparative pharmacology has developed and discuss the relevance of the theoretical basis of measurement scales and the range and scope of currently available tests.

Volume One

0471912387 254pp April $1987 \quad 28.95 / \$ 60.00$

Volume Two

0471912557 approx 310pp January 1989 approx $\mathbf{6 3 5 . 5 0 / \$ 7 3 . 5 0}$

\section{Psychopharmacology and Reaction Time}

Edited by I. HINDMARCH, Human Psychopharmacology Research Unit, University of Leeds, UK, B. AUFDEMBRINKE, Schering Research Laboratories, Berlin, FRG and H. OTT, Schering Research Laboratories, Berlin, FRG

This book emphasizes the wide range of RT applications in situations in psychopharmacology. Contributors consider both methodological and theoretical aspects of RT studies and provide illustrations of the use of RT in both experimental and pragmatic contexts.

0471918180 212pp March $1988 £ 24.50 / \$ 52.50$

\section{Causes, Coping and Consequences of Stress at Work}

Edited by C.L. COOPER, Manchester School of Management, University of Manchester Institute of Science and Technology, UK and R. PAYNE, Manchester Business School, University of Manchester, UK

This book brings together leading international researchers in the field of occupational stress. Each author focusses on recent research findings, theories, methodological issues and actions for coping with stress at work which are relevant to individuals and to organizations.

0471918792 430pp July $1988 \quad 29.95 / \$ 70.00$

\section{International Review of Industrial and Organizational Psychology 1988}

Edited by C.L. COOPER and I.T. ROBERTSON, University of Manchester Institute of Science and Technology, UK

The third in a series of annual reviews, this volume provides an up-to-date and authoritative guide to important areas and developments in the field of Industrial and Organizational Psychology.

047191844X 352pp May 1988 \$35.50/\$82.50

\section{The Origins of Modern Psychiatry}

Edited by $C$. THOMPSON, Charing Cross and Westminster Medical School, London, UK

This volume covers some of the outstanding contributions made to psychiatry during the formative years 1856 to 1938. All the articles included are concerned with controversial subjects and are related to scientific, ethical and social dilemmas.

0471915815 290pp November $1987 \quad 31.95 / \$ 67.50$

\section{Biological Perspectives of Schizophrenia}

Dahlem Life Sciences Research Report 40

Edited by H. HELMCHEN and F.A. HENN

The purpose of this book is to examine the biological processes involved in the etiology and pathogenesis of schizophrenia, to define gaps in our knowledge, and to provide directions for future work. Genetic and nongenetic factors, structural and functional deviations, and neurotransmitters are comprehensively reviewed.

$0471916838368 \mathrm{pp}$ October $1987 \quad$ f42.50/\$87.50

\section{Dementia}

\section{Its Nature and Management}

M. FRASER, University College Hospttal and Friern Hospital, London, UK

Written by a consultant in psychogeriatrics, this practical book discusses the causes, diagnosis and treatment of senile and pre-senile dementia, with particular emphasis on Alzheimer's disease. The author does not deal in hopes and fears, but simply asks, "What can be done about dementia in the 1980 and 1990s?"

$0471915483252 p p$ September $1987 \quad 21.50 / \$ 44.50$

1 iley books are available through your bookseller. Alternatively, order direct from Wiley (payment to John Wiley \& Sons Ltd) Credit card orders accepted by telephone - (0243) 829721 or FREEFONE 3477 . Please note that prices quoted here apply to UK and Europe only.

JOHN WILEY \& SONS LTD

BAFFINS LANE · CHICHESTER · W. SUSSEX PO19 1UD 


\section{The American Psychiatric Press Textbook of Psychiatry}

\section{Edited by J. A. TALBOTT, R. E. HALES and S. C. YUDOFSKY}

Contributions from 55 eminent specialists have been skillfully edited to provide this summary of the latest research and clinical findings in the field of psychiatry. By presenting the most up-to-date research findings in a readable fashion, while emphasising their clinical relevance, the Textbook represents a major contribution to psychiatric education.

$19881324 \mathrm{pp}$.

\section{American Psychiatric Glossary Sixth Edition}

Compiled and edited by E. M. STONE

This essential reference tool has been updated to include the latest developments in psychiatry and the revised nomenclature of the DSM-III Revised. Provides the most complete and current compendium of psychiatric terminology available.

$1988143 \mathrm{pp}$.

o 521364140 Hc $\$ 20.00$ net

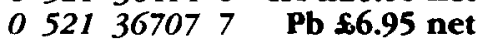

\section{Psychiatry Update}

The American Psychiatric Association Annual Review, Volume 7

Edited by A. J. FRANCES and R. E. HALES This new volume focusses on findings in the areas of: panic disorders; unipolar depression; suicide; electroconvulsive therapy; and cognitive therapy.

$1988697 p p . \quad 0521364183 \quad \$ 35.00$ net

\section{Anxiety and Depressive Disorders in the Medical Patient}

\section{R. DEROGATIS and T. N. WISE}

The authors take a new look at how to conceptualize the psychological and biological aspects of anxiety and depression, how to assess them in patients, and how and when to intervene therapeutically.

c. 256 pp. $0521364175 \$ 20.00$ net Fortbcoming (February 1989)

\section{New Concepts in Psychoanalytic Psychotherapy}

Edited by J. MUNDER ROSS and W. A. MYERS

Researchers are currently drawing on classical psychoanalysis and psychodynamic psychotherapy in therapy in a way far removed from the analyst's couch. Here, the editors provide some guidelines to basic developmental issues, applications, and current controversies, helping to clarify theoretical and research concerns as well as therapeutic ones.

$1988 \quad 312 p p$. O $521364167 \$ 25.00$ net

\section{Limit Setting in Psychiatric Clinical Practice}

\section{S. A. GREEN et al}

Where standard techniques fail to halt regressive acting-out and the patient, therapist, or therapy is threatened, a limit must be set. This book offers a definition of limit setting; examines the theoretical foundations and the transference relationship; and considers the special problems of hospitalized patients. 1988144 pp. $0521350085 \quad \$ 20.00$ net

\section{Cerebral Hemisphere Function in Depression}

Edited by $M$. KINSBOURNE

Here, the editors aim to clarify the functioning of brain areas and neurotransmitters as interacting systems that both generate change in mental state and react to changed mental state. $1988208 p p . \quad 0521364159 \quad \$ 18.50$ net

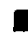

\section{Cambridge University Press}

The Edinburgh Building, Shaftesbury Road, Cambridge CB2 2RU. 


\section{CAMDEX}

The Cambridge Examination for Mental Disorders of the Elderly

SIR MARTIN ROTH, F. A. HUPPERT, E. TYM and C. Q. MOUNTJOY

- a new interview schedule for the diagnosis and measurement of dementia

- easy-to-use, portable and self contained

- comprehensive - combines visual and verbal tests

- acceptable to patients, with high inter-rate reliability,

- sensitive to differentiating organic and non-organic disorders

- detects even low levels of cognition impairment

Devised and tested by Sir Martin Roth and his colleagues, this package comprises a standard assessment and diagnosis of senile dementia. The boxed set includes: a structured clinical interview with the patient; a mini neurological battery comprised of objective cognitive tests; and a structured interview with an independent informant for detailed background information.

$$
1988 \quad 0 \quad 521351618 \quad \$ 50.00 \text { net }
$$

For furtber information on CAMDEX please write to Shelby Howe at the address below. 


\section{CAMBRIDGE}

\section{The Measurement of Moral Judgment}

Volume 1 Theoretical Foundations and Research

Volume 2 Standard Issue Scoring Manual

Edited by ANNE COLBY and the late LAWRENCE KOHLBERG

In collaboration with A. ABRAHAMI, D. CANDEE, J. GIBBS, A. HEWER, A. HIGGINS, K. KAUFFMAN, M. LIEBERMAN, M. NISAN, C. POWER, J. REIMER, D. SCHRADER, J. SNAREY, B. SPEICHER and M. TAPPAN.

This long-awaited two-volume set constitutes the definitive presentation of the system of classifying moral judgment built up by Lawrence Kohlberg and his associates over a period of twenty years. Volume 1 reviews Kohlberg's stage theory, and the large body of research on its significance and utility. Volume 2 , in special user-friendly format, includes three alternative functionally equivalent forms of the scoring system. Researchers in child development and education will find The Measurement of Moral Judgment an indispensable resource.

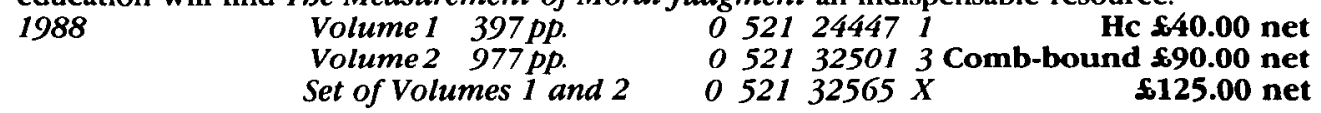

\section{An Introduction to Psychiatric Research}

R. E. GORDON, C. J. HURSCH and K. K. GORDON

With increasing pressure on psychiatrists to demonstrate that their treatment is appropriate and cost effective this book provides the tools for complying with these demands as well as undertaking other scientific enquiries. The authors explain the statistics and research methods used in over $90 \%$ of studies and enable readers to analyze literature and answer their own research questions.

276 pp. $\quad 1988 \quad 0 \quad 521 \quad 350949 \quad \$ 25.00$ net

\section{New Interventions for Children and Youth}

Action Research Approaches ROBERT N. RAPOPORT

The author looks at ten case studies that represent new approaches to mental health problems in young people. Rather than suggesting ways to change the environment or the individual, these projects examine the problems of adapting to the society in which they must live. The successful collaboration between practitioners and scientific researchers in these case studies is also explored.

275 pp. $1988 \quad 0521341221 \quad \$ 27.50$ net

\section{Bereavement and Health}

The Psychological and Physical Consequences of Partner Loss W. STROEBE and M. S. STROEBE

Does the concept of a 'broken heart' have any basis in reality? Bereavement and Health examines scientific evidence bearing on the question of whether persons who have lost a loved one suffer detriments to their mental and physical health. The authors review the empirical research, discuss theoretical contributions and evaluate intervention programmes to reduce the risk of ineffective coping.

288 pp. $1987 \quad 0 \quad 521244706$ Hc $\$ 27.50$ net

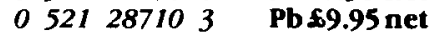

\section{The Child's World of Illness}

The Development of Health and Illness Behaviour SIMON WILKINSON

How do I decide, and convince others, that I am ill? This book explores how the languages of illness are used to present our discomforts to others. By interviewing children between the ages of three and thirteen the author has examined the introduction of illness and the effect this has on health education.

$288 p p$. $1988 \quad 0 \quad 521 \quad 32873 \times \quad \mathbf{E 3 0 . 0 0}$ net

For further information on Cambridge titles in Psychiatry please urite to Jacqueline Arthurs at the address below. 


\section{NOTES FOR CONTRIBUTORS}

PAPERS Papers for publication should be addressed to the Editor, Professor Michael Shepherd, Institute of Psychiatry, De Crespigny Park, Denmark Hill, London SE5 8AF. Contributors should send at least three copies of the text, tables, and figures. Copies other than the first may be xeroxed. The S.I. system should be adopted for text and figures. A short synopsis of about 50 words should be provided at the beginning of each article. Foreign quotations and phrases should be followed by a translation. If necessary, guidelines for statistical presentation may be found in: Altman, D. G., Gore, S. M., Gardner, M. J. \& Pocock, S. J. (1983). Statistical guidelines for contributors to medical journals. British Medical Journal 286, 1489-1493.

Submission of a paper will be held to imply that it contains original work that has not been previously published and that it is not being submitted for publication elsewhere.

In addition to longer articles, the Editor is prepared to accept preliminary and brief communications of between 1500 and 2500 words.

Manuscripts must be typewritten on one side of the paper in double-spacing with wide margins throughout, including references. The following information must be given on a single separate sheet: (1) title and short title for running head (not more than 100 characters): (2) authors' names, and (3) department in which work was done. Footnotes on the same sheet should list: (i) the authors' present addresses if different from departments in which work was done; (ii) name and address of the author to whom correspondence should be addressed; (iii) receipt of grants. Authors who would like a reprint address to be printed should include this on their manuscript.

REFERENCES (1) In the text these should follow the Harvard system - that is, name followed by date: Brown (1970). If there are more than two authors the first author's name followed by et al. should be used, even the first time that the reference appears. (2) The list of references should be typed in alphabetical order on a separate sheet and should appear as follows: Brown, J., Williams, E. \& Wright, H. (1970). Treatment of heroin addiction. Psychological Medicine 1, 134-136. Journal titles should be given in full.

Books should be cited as follows: Brown, J. (1970). Psychiatric Research. Smith: Glasgow.

Articles from edited books should be cited as follows: Brown, G. W. (1974). Meaning, measurement and stress of life events. In Stressful Life Events: Their Nature and Effects (ed. B. S. Dohrenwend and B. P. Dohrenwend), pp. 217-244. John Wiley: New York.

ILlustrations Only essential figures and tables should be included. Photographs Unmounted photographs on glossy paper should be provided. Magnification scales, if necessary, should be lettered on these. Where possible, prints should be trimmed to column width (i.e. $70 \mathrm{~mm}$ ). Diagrams These will usually be reduced to $70 \mathrm{~mm}$ wide. Lettering should be in either Letraset or stencil, and care should be taken that lettering and symbols are of comparable size. Illustrations should not be inserted in the text, they should be marked on the back with figure numbers, title of paper, and name of author. All photographs, graphs, and diagrams should be referred to as figures and should be numbered consecutively in the text in Arabic numerals. The legends for illustrations should be typed on a separate sheet. Tables Tables should be numbered consecutively in the text in Arabic numerals and each typed on a separate sheet.

PROOFS AND OFFPRINTS Page proofs will be sent to the senior author. Corrections other than printer's errors may be charged to the author. Fifty offprints of each paper are supplied free; additional offprints are available according to a scale of charges if they are ordered when the proof is returned. 


\title{
Psychological Medicine
}

\author{
Volume 19 Number 1 February 1989
}

\section{CONTENTS}

Editorials

Iatrogenic transmission of Creutzfeldt-Jacob disease R. O. WELLER

Congenital risk factors for schizophrenia S. W. LEWIS

Citation trends of general psychiatric journals G. G. LLOYD \& A. E. FLETCHER

Renvoize, E. B. \& Beveridge, A. W. Mental illness and the late Victorians: a study of patients admitted to three asylums in York, 1880-1884

TURner, T. Rich and mad in Victorian England 29

Kendell, R. E. Clinical validity 45

RoBins, L. N. Diagnostic grammar and assessment : translating criteria into questions

Hunter, R., Christie, J. E., Whalley, L. J., Bennie, J., Carroll, S., Dick, H., Goodwin, G. M., Wilson, H. \& FINK, G. Luteinizing hormone responses to luteinizing hormone releasing hormone (LHRH) in acute mania and the effects of lithium on LHRH and thyrotrophin releasing hormone tests in volunteers

69

Irving. J. B., Coursey, R. D., Buchsbaum, M. S. \& MurPhy, D. L. Platelet monoamine oxidase activity and life stress as predictors of psychopathology and coping in a community sample

JoHNSTONE E.C. OWENS, D G C BYDPER G M Colter, N., Crow, T. J. \& Frith, C. D. The spectrum of structural brain changes in schizophrenia : age of onset as a predictor of cognitive and clinical impairments and their cerebral correlates

VieweG, W. V. R., Godleski, L. S., Mitchell, M., Hundley, P. L. \& YANK, G. R. Abnormal diurnal weight gain among chronically psychotic patients contrasted with acutely psychotic patients and normals 105

Calev, A., Ben-Tzvi, E., Shapira, B., Drexler, H., Carasso, R. \& Lerer, B. Distinct memory impairments following electroconvulsive therapy and imipramine 111

Gurese, $O$. The significance of subtyping tardive dyskinesia: a study of prevalence and associated factors 12 I

Coryell, W., Keller, M., Endicott, J., Andeasen, N., Clayton, P. \& Hirschfeld, R. Bipolar Il illness: course and outcome over a five-year period

129

Whitaker, A., Davies, M., Shaffer, D., Johnson, J., Abrams, S., Walsh, B. T. \& Kalikow, K. The struggle to be thin: a survey of anorexic and bulimic symptoms in a non-referred adolescent population

143

GoOdyer, I. M., Wright, C. \& Altham, P. M. E. Recent friendships in anxious and depressed school age children
Godfrey, H. P. D., KNight, R. G., MaRsh, N. V., Moroney, B. \& Bishara, S. N. Social interaction and speed of information processing following very severe head-injury

KING, M. Locus of control in women with eating pathology

Huxley, P., Raval, H., Korer, J. \& JaCoB, C. Psychiatric morbidity in the clients of social workers: clinical outcome

\section{Brief Communications}

Seasonal variation in suicide: is there a sex difference? R. Micciolo, C. Zimmerman-Tansella, P. Williams \& M. TANSELLA

The effects of sexual assault on men: a survey of 22 victims G. MezeY \& M. King

Caffeine abstention in the management of anxiety disorders M. S. BRUCE \& M. LAder

Preliminary Communications

Autobiographical memory. Sensitivity to age and education of a standardized enquiry G. BORRINI, P. DALL'ORA, S. D. Sala, L. Marinelli \& H. SPINNLER 215

Validation of a computerized assessment (PROQSY) of minor psychological morbidity by Relative Operating Characteristic analysis using a single GP's assessments as criterion measures G. WILKINSON \& A. C. MARKUS 225

Research Report

Recent research activities in WHO's mental health programme N. SARTORIUS

Book Reviews

Arthur Wigan and the Duality of the Mind A. HARRINGTON

245

The Benzodiazepine Receptor I. L. MARTIN 247

Cancer Surveys: Advances and Prospects in Clinical, Epidemiological and Laboratory Oncology K. RAWNSLEY 248

Current Problems in Neurology: 5: Impact of Functional Imaging in Neurology and Psychiatry E. JOYCE 249 Neurobehavioural Recovery From Head Injury N. BROOKS

Short Reviews 251

PSYCHIATRY IN THE 1880s 265

American Journal of Psychiatry Contents OctoberDecember $1988 \quad 267$

Journal of Nervous and Mental Disease Contents JulySeptember $1988 \quad 270$

\section{Indexed in Current Contents}

(C) Cambridge University Press 1989

\section{CAMBRIDGE UNIVERSITY PRESS}

The Pitt Building, Trumpington Street, Cambridge CB2 IRP

32 East 57th Street, New York, NY 10022, USA

10 Stamford Road, Oakleigh, Melbourne 3166, Australia

Printed in Great Britain by the University Press, Cambridge 